\title{
The concept of public works in India
}

\author{
P. RATNESH \\ University of Debrecen, Faculty of Economics and Business Ihrig Károly Doctoral School, Ph.D. Student, Debrecen, \\ Hungary, ratnesh.18011991@gmail.com.
}

Abstract. The objective of this paper is to understand the concept of public work in India. Nowadays we may approach a wide and broad understanding of public work on international level. One aspect is working for the government. Another one is associated with fighting unemployment and providing work possibility for the unemployed (by doing this decreasing poverty). It may also be understood as participated in governmental financed construction programmes and NREG is one such programme which helps to generate employment for the poor people in India. In this paper various aspects about public works in India are discussed.

Keywords: Public work programs, National Rural Employment Guarantee (NREG), Poverty, Employment.

\section{The work supported by the, Faculty of Economics and Business Ihrig Károly Doctoral School, University of Debrecen. The author is thankful to this financial support to carry out this research.}

\section{Introduction}

In general, the term public works refers to community-based and public financed programs that support poor and food insecure people, including by providing a source of income, or transfers in cash, or in-kind by generating employment and creating, maintaining, or rehabilitating assets and infrastructure.

There is increasing awareness and involvement in public works programs [1] around the world. For example, recent analyses show that they are currently in about 80 developing countries, with an exponential growth over the past decade. Most of these programs have been focused on strong impact estimations and are carefully documented in a range of published materials and resources [2].

India is one of the few countries in the developing world to have implemented public works as early as 1950 's, shortly after independence, with the main objective of providing temporary employment during the agricultural slack season. Unlike in some African countries, India over time developed in-house capacity to implement the program, so that when hit by a major drought, its program was ready to expand. This program came in handy when its country was hit by a massive drought in 1987, often known as the drought of the century. The program protected the poor from severe consumption shortfall [3].

The motivation here is to guarantee employment at a low wage when demanded by workers. In other words, workers here enjoy the freedom to move in (when market wage is low or work not available) and out (when the market wage is better than the public works wage). So Public work programs here provide an "option price" to workers to be used when needed. In South Africa, for example, find that 
some districts with high levels of poverty and unemployment had no public works projects, while others with low levels of poverty had benefited from several. [4]

The Maharashtra Employment Guarantee Scheme in India, which is currently being nationally expanded through the 'National Rural Employment Guarantee Act 'falls in this category. Specifically, the Act mandates all state governments to provide at least 100 days of guaranteed wage employment to household's adult members who are willing to do casual manual labour at the statutory minimum wage [5].

The most common way for governments and organizations to explain poverty is to break it down into two facets: absolute poverty and relative poverty. In general, absolute poverty means that a person's basic subsistence needs (for food, clothing, and shelter) are not being met. Relative poverty, on the other hand, typically means that a person's needs are not being met in comparison to the rest of his or her society [6].

The aim of this paper is to understand the framework of public works in India and how public works are helping in generating job opportunities and reduce poverty.

\section{Methodology}

This paper is theoretical in nature.It is constructed only on a review and analysis of research and data from the literature. Several methods were employed to collect and analyze the literature. "Secondary analysis is a method of research in which the data collected and processed by one researcher are reanalysed for a diverse purpose-by another researcher" [7].

A vital part of the research is the process of the conceptualization, and mainly the information found on the official website of Government of India, The Central Public Works Department \& NREG, journal articles, internet etc. were used to analyse the literature and to write this article.

\section{History and structure of Public Works in India}

The Central Public Works Department (CPWD) is a 157 year old institution and is the principal agency of the Government of India responsible for creating assets and providing comprehensive services including planning, designing, construction and maintenance of office \& residential buildings as well as other structures of various ministries and departments of Government of India and other autonomous bodies and public sector enterprises [8].

The Central Public Works Department (CPWD) came into existence in July 1854 when Lord Dalhousie established a central agency for execution of public works and set up Ajmer Provincial Division. Through the professional expertise in disciplines including Architecture, Engineering, Project Management coupled with comprehensive experience in building construction and maintenance CPWD has been serving the nation for last 162 years and has executed priority of works in difficult and demanding geographical and climatic conditions. It has now grown into a comprehensive construction management department, which provides services from project concept to completion, consultancy and maintenance management. 
It is headed by DG who is also the Principal Technical Advisor to the Government of India. The regions and sub-regions are headed by Special DGs and Additional DGs respectively, while the zones in all state capitals (except a few) are headed by Chief Engineers. CPWD has PAN India presence and has ability to undertake construction of complex projects even in difficult terrain and maintenance in post construction stage.

\subsection{Public Works Programs}

Public works programs (PWPs) designed as a major anti-poverty program provide substantive income support to poor families in countries with a large segment of poor unemployed or underemployed workers. In those cases, programs are launched and implemented pretty much throughout the year and are also likely to hire people for longer periods of time. Moreover, they may also use explicit targeting mechanisms in addition to or instead of self-targeting induced by setting the wage rate at an appropriate level. (Roy, 2006) [9]. Among an extensive variability of public works programs three specific forms which are the most:

- Public work programs (PWPs), which may give payments in cash or in-kind benefits for work. This more common and traditional form is often adopted as a temporary response to specific shocks and crises, as well as having a longer-term horizon as part of predictable and multi-year programs. These programs are often also called Public Work Programs by some institutions.

- Employment guarantee schemes (EGSs) refer to long term rights-based programs in which some level of right to work is given to those who enroll.

- Public investment programs (PIP) are public investments in rural or urban infrastructure. For example, in rural infrastructure, countries' investment in rural roads, irrigation, and water management and supply.

These programs provide prospects for job creation when labor-based skills are used and small-scale contracting modalities, including public contracting is used for execution. While PWPs can contribute to numerous development objectives, they are not able to aid all objectives to the same level at the same time [10].

In practice, the policy design and execution involve the prioritization of one role over others, along the subsequent outlines:

- Employment function: Importance on job creation in programs that focus on the state as the employer of last resort.

- Social protection function: Stress on income safety and transfers is mostly done in cash.

- Labor-based investment function: Importance on the quality and nature of substructure made, assets created, or services provided. 


\section{National Rural Employment Guarantee (NREG) the world's largest public works program.}

NREG is the latest in a succession of rural employment programs in India. The primary objective is to provide wage employment to un and under-employed agricultural laborers, but it also aims produce and restore public goods, typically in the form of local infrastructure, and to promote decentralized governance. Despite the precursors, the passing of the National Rural Employment Guarantee Act (NREGA) in 2005 was widely seen as a significant event.

In addition to providing 'enhancement of livelihood security of the households in rural areas of the country by providing at least 100 days of guaranteed wage employment to every household in unskilled manual work' [5].

The act also created other entitlements: Work is to be provided within 15 days of receipt of a written or oral job application. Applicants are entitled to an unemployment allowance if the local government fails to provide work, and to a transport allowance if the site is more than $5 \mathrm{~km}$ from their home.

The act stipulates equal wages for men and women, and it sets down some minimum standards for the worksites, including access to drinking water, shade and childcare.

The Maharashtra Employment Guarantee Scheme in India, which is currently being nationally expanded through the 'National Rural Employment Guarantee Act 'falls in this category. Specifically, the Act mandates all state governments to provide at least 100 days of guaranteed wage employment to household's adult members who are willing to do casual manual labour at the statutory minimum wage [11]. The works under NREG are 'demand driven' instead of supply driven. Every adult of the listed families under NREG may request work when they need, and the government must provide hundred days of guaranteed wage employment to every household who so ever has been recorded under the scheme.

Central government is making large public disbursement under NREG. In the recent budget 2009-10, an allocation of Rs 39,100 crore has been made for MNREGA, which is an increase of 144 per cent over the 2008-09 budget 16,000 crore [12]. Under such situations it turns out to be essential to assess how far the program is accomplishing its anticipated goals in terms of empowering the rural people.

\section{Training of Public Workers.}

Training is one of the most important aspect to make the more effective and for this the government has several training centers across the country. The Regional Training Institutes are located at R.K.Puram, New Delhi, New Marine Lines, Mumbai, Salt Lake City, Kolkata and Besant Nagar, Chennai. The Regional National Academy conduct training courses for Group B \& C officials.

Workers Training Centres also work as part of Regional National Academy. They impart skill improvement training to workers and staff. The skill development courses for workers are conducted 
in associated with "Construction Industry Development Council". After completion of the training, certification of the workers is also done through "IGNOU" [13].

The National CPWD Academy is looking after the training needs of Engineers, Architects, Horticulturists and workers. The main academy is located at Ghaziabad. Regional National Academy and Workers Training Centres are in the four metros i.e. New Delhi, Mumbai, Kolkata and Chennai.

The National CPWD Academy is in a lush green, serene, salubrious and pollution free environment spread over 30 acres of land in Kamla Nehru Nagar, Ghaziabad nearly $30 \mathrm{~km}$. from New Delhi Railway Station and $32 \mathrm{Km}$. from Nirman Bhawan, New Delhi.

The Institute imparts training/refresher courses in all the aspects of public works. The academy conducts training programmes, workshops, brain-storming sessions, seminars etc. to upgrade the techno-management skills of CPWD officers as well as other Central Government Departments, State Government, PSUs etc. The training programmes are conducted in diverse streams such as Civil Engineering, Electrical and Mechanical Engineering, Architecture, Computer Application and Management Techniques.

Several new courses on Green Buildings, their rating system and certification, energy efficient buildings, conservation of heritage buildings etc. have been introduced to cater to the current changing construction scenario.

New courses on Horticulture have also been added. It can clearly be understood that how important the concept of public work is in India where high percentage of people are below the poverty line and unemployed. We could identify those good methods and practices, solutions, leverages, which are suitable to imply in the public work management.

We also can reach to a conclusion that by giving training there is a potential to lead public worker back to primary market and decreasing poverty and NAREGA scheme plays a vital role in generating sustainable public work on a large scale across the country.

Though India boasts of a high economic growth of 6.13\% in 2017, there is still large-scale poverty in India and there is a direct impact a strong public work The government, local municipalities may also have some responsibility in providing meaningful activity for the rural citizens as a form of public work.

It seems that to fight against poverty, where both public work and agricultural sector should have a very important role in the empowerment of the poor it is high time that the government takes some serious steps.

\section{Conclusion}

It can clearly be understood that how important the concept of public work is in India where high percentage of people are below the poverty line and unemployed. We could identify those good methods and practices, solutions, leverages, which are suitable to imply in the public work management. 
We also can reach to a conclusion that by giving training there is a potential to lead public worker back to primary market and decreasing poverty and NAREGA scheme plays a vital role in generating sustainable public work on a large scale across the country.

Though India boasts of a high economic growth of 6.13\% in 2017, there is still large-scale poverty in India and there is a direct impact a strong public work The government, local municipalities may also have some responsibility in providing meaningful activity for the rural citizens as a form of public work.

It seems that to fight against poverty, where both public work and agricultural sector should have a very important role in the empowerment of the poor it is high time that the government takes some serious steps in implementing these public work programs more efficiently.

\section{References}

[1] A. Barrientos - D. Hulme (2008) Social Protection for the Poor and Poorest. (Eds.) Palgrave.

[2] G. Berhane - J. Hoddinott - N. Kumar - A. Taffesse - M. Diressie - Y. Yohannes - R. SabatesWheeler (2011) Evaluation of Ethiopia's Food Security Program: Documenting Progress in the Implementation of the PSNP and the HABP. IFPRI, Washington DC.

[3] R. Dilip (2006) Public Works in Bangladesh: Current Status and its Role as Unemployment Insurance. World Bank, Washington, DC. Mimeo.

[4] M. Adato - L. Haddad. (2001) How Efficiently Do Public Works Programs Transfer Benefits to the Poor? Evidence from South Africa. Discussion Paper 108. Washington, DC: International Food Policy Research Institute.

[5] Government of India. (2008) National Rural Employment Guarantee Act 2005 (NREGA): Two Years 2006-2008. Ministry of Rural Development, New Delhi.

[6] G. M. Fisher (1994) Is There Such a Thing as an Absolute Poverty Line Over Time? Evidence from the United States, Britain, Canada, and Australia on the Income Elasticity of the Poverty Line."

[7] E. Babbie (1990) Survey Research methods, secondary Analysis. The Practice of Social Research. Ch (10) pp. 262-264.

[8] Government of India. (2010) Ministry of Housing \& Urban Affairs Central Public Works Department for Excellence in Public Works, New Delhi.

[9] R. Dilip. (2006) Public Works in Bangladesh: Current Status and its Role as Unemployment Insurance. World Bank, Washington, DC. Mimeo.

[10] Inter-Agency Social Protection Assessments (ISPA) (2015) Public Works Social Protection Programs.

[11] Government of India. (2005) National Rural Employment Guarantee Act 2005 (NREGA): Two Years 2006-2008. Ministry of Rural Development, New Delhi.

[12] Institute of Applied Manpower Research. (2007) All-India Report on Evaluation of NREGA A Survey of Twenty Districts. New Delhi.

[13] Government of India. (2012) Ministry of Housing \& Urban Affairs Central Public Works Department for Excellence in Public Works, New Delhi. 